\title{
Hormonal Control of Adipose Tissue Metabolism, with Special Reference to the Effects of Insulin*
}

\author{
The Banting Memorial Lecture delivered on September 25, 1964 before the Medical and Scientific Section \\ of the British Diabetic Association, at the Middlesex Hospital Medical School, London, England
}

\author{
By \\ Albert E. Renold, Oscar B. Crofford, Werner Stauffacher and Bernard Jeanrenaud \\ From the Institut de Biochimie Clinique, Université de Genève, Geneva
}

Received May 4, 1965

Summary. What we would like to have accomplished in this discussion, is perhaps mainly to have emphasized once more the likelihood that adipose tissue is a predominant site of insulin action, perhaps the predominant site. Insulin would seem to be the primary hormone of energy storage, favouring both the deposition and the retention of the major energy store: fat in adipose tissue. While it may still be true, that both these effects - storage and retention - are the result of just one primary action increased glucose transport - a separate effect directly resulting in decreased fatty acid mobilization may be an important aspect of this control, as well. We consider the availability for study of isolated adipose tissue cells, which still appear to be fully responsive to insulin, a major advance, holding the promise of arriving some day at a true understanding of the intimate mechanism of insulin action. When considering the regulation of fat release from adipose tissue, it would seem that closer scrutiny of the controlling importance of blood and plasma flow through the tissue might well be warranted.

Adipose tissue is no longer considered a static tissue; it is recognized as what it is: the major site of active regulation of energy storage and mobilization, one of the primary control mechanisms responsible for the survival of any given organism. Although general recognition of the important role played by adipose tissue has abruptiy increased during the past ten years, it remains for the future to provide us with a detailed understanding of many aspects of the control systems which are operative in each instance.

Résumé. Nous avons résumé dans cette leçon les arguments qui nous poussent à penser que l'action de l'insuline sur le tissu adipeux est une des actions les plus importantes, peut-être bien l'action principale même de cette hormone. En effet, il semble de plus en plus probable, que l'insuline est l'hormone anabolique par excellence, favorisant aussi bien l'accumulation que la rétention de la principale réserve calorique de l'organisme, soit les triglycérides du tissu adipeux. Une action importante de l'insuline sur le tissu adipeux est certainement celle d'accélérer le transport du glucose au niveau de la membrane cellulaire, et il semblerait que cette accélération pourrait résulter de l'affinité plus grande d'une composante du mécanisme de transport pour le glucose. Le mécanisme de transport du glucose au niveau de la membrane de ce tissu correspond bien aux critères d'une diffusion facilitée utilisant un transporteur mobile, tout comme c'est le cas pour les cellules musculaires, les érythrocytes ou les levures. Si

* Delivered by Albert E. Renold. Parts of this paper have also served as basis for parts of the 20th Jacobaeus Lecture, delivered at the Niels Steensens Hospital Auditorium in Copenhagen, Denmark, March 1965.

The studies reported on here have been supported by grant $\mathrm{N}^{\circ} .2343$ of the Fonds National Suisse de la Recherche Scientifique and by a grant-in-aid from the Fondation Emil Barell pour le Développement des Recherches Médico-scientifiques. l'importance de l'action insulinique au niveau du transport du glucose est acquise, il n'est pourtant pas possible d'expliquer tous les effets de l'insuline sur le tissu adipeux au moyen de cette seule action. En particulier, il est probable que l'insuline agisse également de facon directe en inhibant la mobilisation des acides gras, soit au niveau de la lipolyse, soit au niveau du transfert des acides gras au travers de la membrane cellulaire. Nous pensons que la possibilité qui existe maintenant d'étudier des cellules adipeuses isolées en suspension, cellules gardant leur sensibilité à l'insuline, est un important pas en avant et nous permettra peut-être d'analyser plus en détail le mécanisme d'action de l'hormone.

Le tissu adipeux n'est plus considéré comme un tissu statique. Son importance pour l'homéostase de l'organisme est pleinement reconnue, importance qui découle de la présence au niveau de ce tissu des mécanismes de contrôle qui sont responsables de l'accumulation et de la mobilisation des réserves énergétiques, done de facteurs qui contribuent de façon essentielle à la capacité de survie de tout organisme. Nous pensons que parmi les mécanismes de contrôle qui ont été considérés, une importance insuffisante a été donnée jusqu'ici aux facteurs servant à régler le débit sanguin et plasmatique de ce tissu, et par là l'apport d'albumine au voisinage de la cellule adipeuse, albumine nécessaire à la, solubilisation et au transport des acides gras libérés de la cellule. Si au cours de ces dernières dix années nous en sommes venus à reconnaître clairement le rôle important que joue le tissu adipeux dans l'homéostase énergétique, il faut bien reconnaître également que nos connaissances ne s'étendent encore qu'à certains aspects du métabolisme de ce tissu, et qu'un nombre bien plus grand reste à découvrir.

Zusammenfassung. Was wir in dieser Diskussion ausführen wollten, ist vielleicht vor allem der nachdrückliche Hinweis darauf, daß das Fettgewebe wahrscheinlich ein Hauptangriffspunkt, wenn nicht sogar der Hauptangriffspunkt der Insulinwirkung ist. Insulin scheint das wichtigste Hormon der Energiespeicherung zu sein, indem es sowohl die Ablagerung als auch die Erhaltung des energiereichsten Vorratsstoffes, nämlich der Triglyceride im Fett. gewebe fördert. Wenn es auch heute noch möglich scheint, daß diese beiden Vorgänge, Ablagerung sowie Erhaltung, die Folge einer einzigen Primärwirkung des Insulins, nämlich des gesteigerten Glukosetransportes, sind, so scheint es doch wahrseheinlicher, daß das Hormon noch direkt eine verminderte Freisetzung von Fettsäuren als gesonderten Effekt bewirkt. Daß nunmehr der Untersuchung des Fettgewebes isolierte Fettzellen zur Verfügung stehen, deren Ansprechbarkeit für Insulin voll erhalten zu sein scheint, halten wir für einen großen Fortschritt in dem Bestreben, eines Tages den tatsächlichen Mechanismus der Insulinwirkung voll durchschauen zu können. Was die Regulation der Fettfreisetzung aus dem Fettgewebe betrifft, so erscheint es uns wichtig, sich der näheren Erforschung der Bedeutung des Blut- und Plasmaflusses durch das Gewebe für diesen Steuerungsmechanismus intensiv zuzuwenden. 
Man sieht heute das Fettgewebe nicht mehr als stoffwechselträges Gewebe an, sondern als das, was es ist, nämlich als den Hauptsitz der aktiven Regulation der Energiespeicherung und Energiemobilisation, also einer der wichtigsten Steuerungsmechanismen für das Überleben jedes
Organismus. Obwohl die bedeutende Rolle des Fettgewebes in den letzten Jahren immer allgemeiner anerkannt wird, verbleibt uns doch für die Zukunft die Aufgabe, uns um die genaue Erkenntnis der Einzelheiten der vielfälti gen Steuerungssysteme zu bemühen.
It is difficult to believe today that ten years ago very few investigators thought about adipose tissue as a site of active metabolic regulation. Yet today, Dr. George CAHILL and I have just completed the editorial work concerned with the publication by the American Physiological Society of a volume of the Society's Handbook of Physiology, a volume devoted entirely to adipose tissue (RENOLD and CAHILL, 1965). It comprises some 70 chapters and its cumulative bibliography lists well over 4000 references! In the volume Dr. H.E. WERTHFIMER, of Jerusalem, provides a perspective of the scientific development of the field, a perspective for which he is particularly qualified, since he and Dr. F.X. HaUsberger, of Philadelphia, are the two pioneers who foresaw many of the then future, now present developments in their studies and reports begun in the late twenties. Dr. WERTHEIMER is also responsible for a first and vigorous increase in general interest in adipose tissue which followed his publication, together with Dr. B. ShaPIRo, of the first review of adipose tissue physiology, published in 1948 in Physiological Reviews. That review emphasized, as did subsequent work from Dr. WeRThemmer's laboratory that adipose tissue has an active, independent metabolism and that it is capable of synthesizing fatty acids as well as depositing them after their absorption from the intestinal tract, or their synthesis in other tissues, such as the liver.

The second and decisive increase in general interest for the tissue was generated in 1956, when three groups of workers (LAURELL; DOLE; GORDON and CHERKES) independently reported on a new and metabolically highly active fraction of lipid in plasma which was termed unesterified fatty acid (UFA), non-esterified fatty acids (NEFA), and known by general agreement under the term of free fatty acids (FEA). Observations such as that shown in Figure 1, provided biochemists, physiologists and clinicians with a measurable entity reflecting primarily the mobilization of fat from adipose tissue, an entity furthermore, which in most instances responded by easily measurable changes in concentration to alterations in the rate of their release. From that time on, interest in adipose tissue reached its explosive phase of development, resulting in literally thousands of studies over a period of a few years.

It is a pleasant duty for me to acknowledge here the presence of at least two individuals whose interest in adipose tissue antedated considerably this explosive period: Professor KEckwICK, whose Bradshaw Lecture "on Adiposity" beautifully summarizes many years of work concerned with the fat depots (1960), and Dr. R.D. LAwRENCE, whose deep concern with the relationships between disturbed lipid metabolism in diabetes and the state of adipose tissue was so particularly well described in his first report of a patient with lipoatrophic diabetes in 1946.

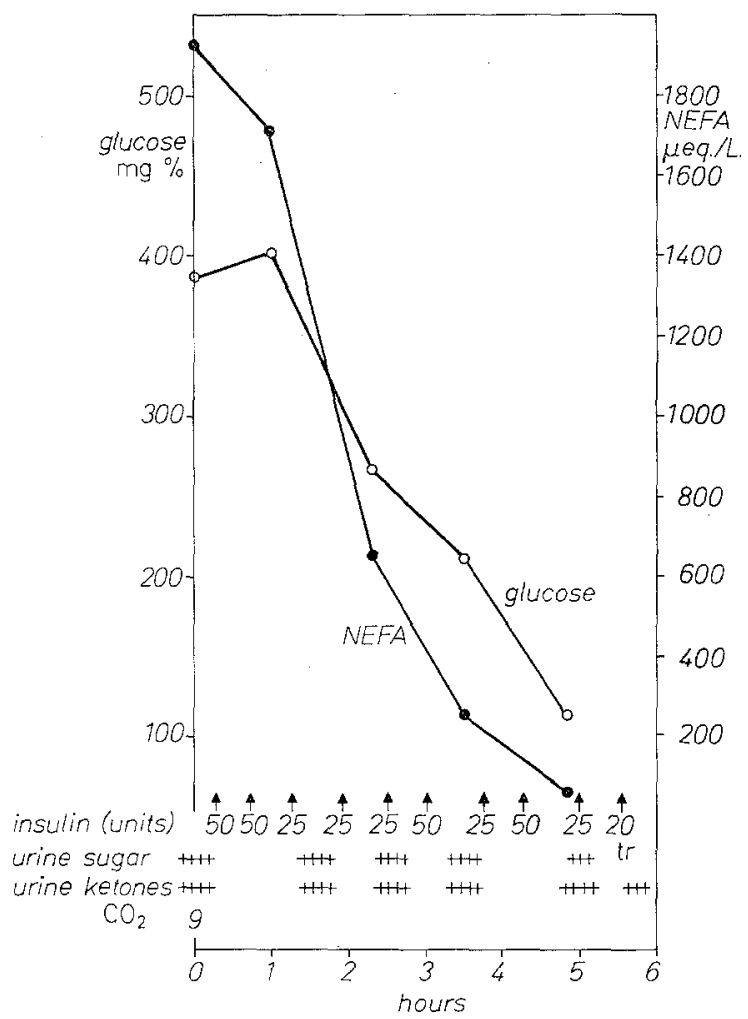

Fig. 1. Diabetic coma ( $9,17 \mathrm{yrs})$. Course during insulin therapy. From E. L. BIERMan, V.P. DoLe and T.N. RoberTs, Diabetes $6,475,1957$

My own interest in adipose tissue, if I may be permitted in this lecture a very brief autobiographic capsule, was clinically induced. The first problem which was suggested to me as a subject for work by Dr. Alexander Marble and Dr. Elliototr P. Joslin, was that of the lipodystrophies which occur in diabetic patients at the site of insulin injections. At that time, in 1948, the year of publication of the review by WERTHEIMER and SHAPIRO, we felt convinced that these lipodystrophies were likely to represent a true effect of insulin rather than some artefact contingent upon either contamination or inadequate injection technique. An attempt was made to reproduce these lipodystrophies in a laboratory animal, the albino rat, and although the atrophic form was never obtained, the hypertrophic form could be easily reproduced (RENOLD, MARBLE and FAWCETT, 1950). Of greater importance, perhaps, was the observation, illustrated by figure 2 that insulin exerted a local effect upon adipose tissue, which could not be explained as an indirect one, through its action on some other tissue. This was, I believe, the first 
unequivocal demonstration of a direct effect of insulin on rat adipose tissue, an effect which was soon confirmed by the observation of KraHL (1951) who first described an effect of insulin upon isolated adipose tissue, while HAUSBERGER and his group analyzed the deviations from normal of the metabolism of adipose tissue obtained from diabetic animals or from animals pretreated with insulin (HAUSBERGER et al. 1954). In 1956 and 1957 Dr. WINEGRAD and I (RENold et al. 1957, WINEGRAD and RENOLD, 1958) introduced the use of the paired epididymal adipose tissue from the rat, untraumatized and uncooled, for the study of regulatory effects upon glucose metabolism by adipose tissue, a procedure which was rapidly taken up by GoRDoN and Cherkes (1958) for the study of free fatty acid release. What most impressed us, at that time, was the

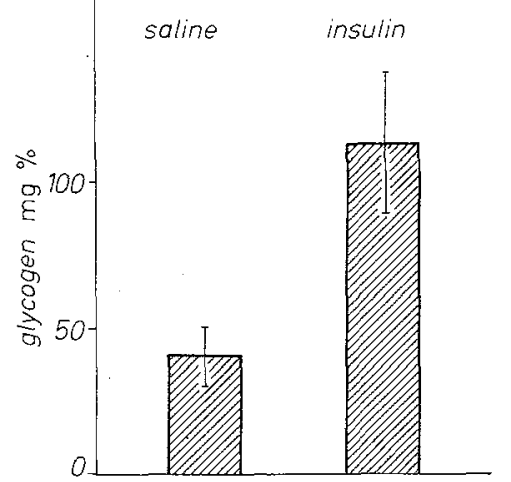

Fig. 2. Local action of insulin in 6 diabetic rats. (PZI 5 units into left groin fat, equal volume saline into right groin fat. Glycogen measured 20 hours later). From ReNOLD, MaRbLE and FAWCETT, 1950

degree of the metabolic effectiveness of physiologic levels of hormones such as insulin and we proposed, therefore, that the effects of certain hormones on adipose tissue might well be their major regulatory effects within the body (RENoLD et al. 1959 and 1960; CAFILL et al. 1959).

We shall now attempt to summarize some of our present-day concepts of the hormonal control of adipose tissue, more specifically of that control which is concerned with the creation and the preservation of fat stores, and therefore more particularly, as we shall see, with glucose and insulin.

Figure 3 schematizes the major metabolic reactions concerned with energy storage in adipose tissue. The numbers in this Figure indicate important sites of control, which we shall refer to in the course of the discussion. An unquestioned major site of control (Fig. 3 No. 1) is the rate at which glucose is made available to metabolism within the cell and at this step, clearly, the role of insulin is the predominant one. The amount, detail and quality of the information available on the effects of insulin on glucose metabolism by adipose tissue is best illustrated by Figure 4, taken from a study by FlatT and BALL (1964, 1965). It is apparent that insulin not only increases glucose uptake but that it radically alters the metabolism of glucose at all steps which have been measured. Since so many metabolic fates of glucose are influenced, it is likely that the primary metabolic event is an early one, presumably at the level of the transformation of extracellular free glucose into intracellular glucose-6-phosphate. Even when glucose metabolism in a certain area is decreased by the presence of insulin, as in the Krebs-TCA cycle, FLATT and BaLL could demonstrate that this is a logical consequence of increased glucose metabolism elsewhere in the tissue, more specifically of the relative accumulation of reduced cofactors characteristic of accelerated glucose metabolism in a tissue actively synthesizing fatty acids.

During the past two years, we have therefore concentrated our interest on an analysis of the initial effect of insulin on glucose metabolism in adipose tissue.

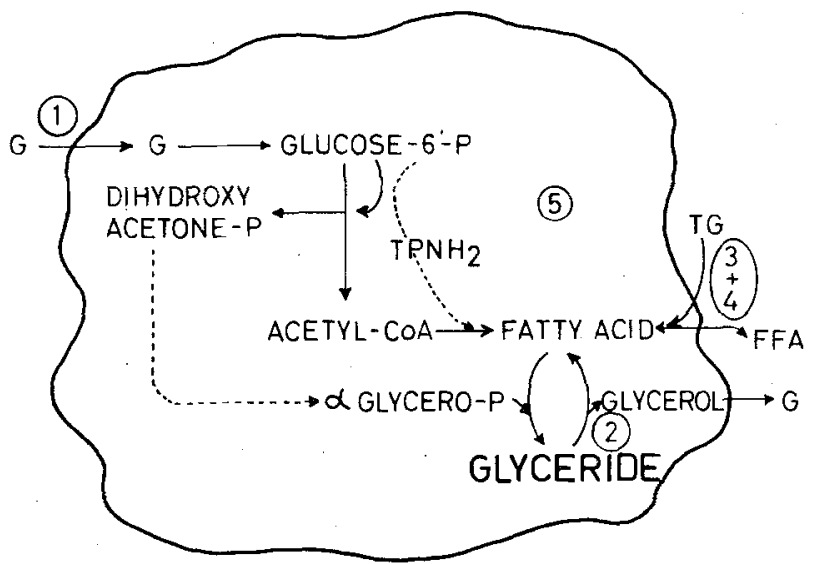

Fig. 3. Sehematic representation of major metabolie pathways in normal adipose tissue

In so doing, we have followed the leads provided for us in other tissues by the concepts of Levine and GoLDSTEIN (1955) as well as of the work originating from the groups of PaRK and Morgan in Nashville (PARK et al. 1959, Morgan et al. 1964), KIPNIS and CorI in St. Louis (KrPNIs, 1959) and RANDLE and his collaborators in Cambridge, now Bristol (RANDLE and MoRGAN, 1962). We have felt that this was necessary work, since identity of the effects of any one hormone on several tissues may never be assumed, as evidenced with particular clarity in the case of insulin by a comparison of its effect on muscle, on the one hand, and liver, on the other. Just why this analysis of insulin action on adipose tissue had to wait from 1958 to 1964 became soon apparent when we began our studies of the spaces available for the distribution of different substances in this tissue (CROFFORD and RENoLD, 1964 and 1965). Whereas the total water space of muscle is of the order of $75 \mu \mathrm{l}$ per $100 \mathrm{mg}$ of tissue, one third of this being extracellular and two thirds intracellular, the total water space of adipose tissue is of the order of $15 \mu \mathrm{l}$, two thirds of this being extracellular and only one third intracellular. Since in the course of the studies to be carried out it was of prime importance to measure, with reasonable accuracy, concentrations of 
substances within intracellular water, the first problem which confronted us was evidently that of attaining sufficient accuracy in all of our analytical procedures to be able to estimate intracellular concentration under these conditions. This is not the place to detail these methodological aspects of our studies, but their importance should be underlined.

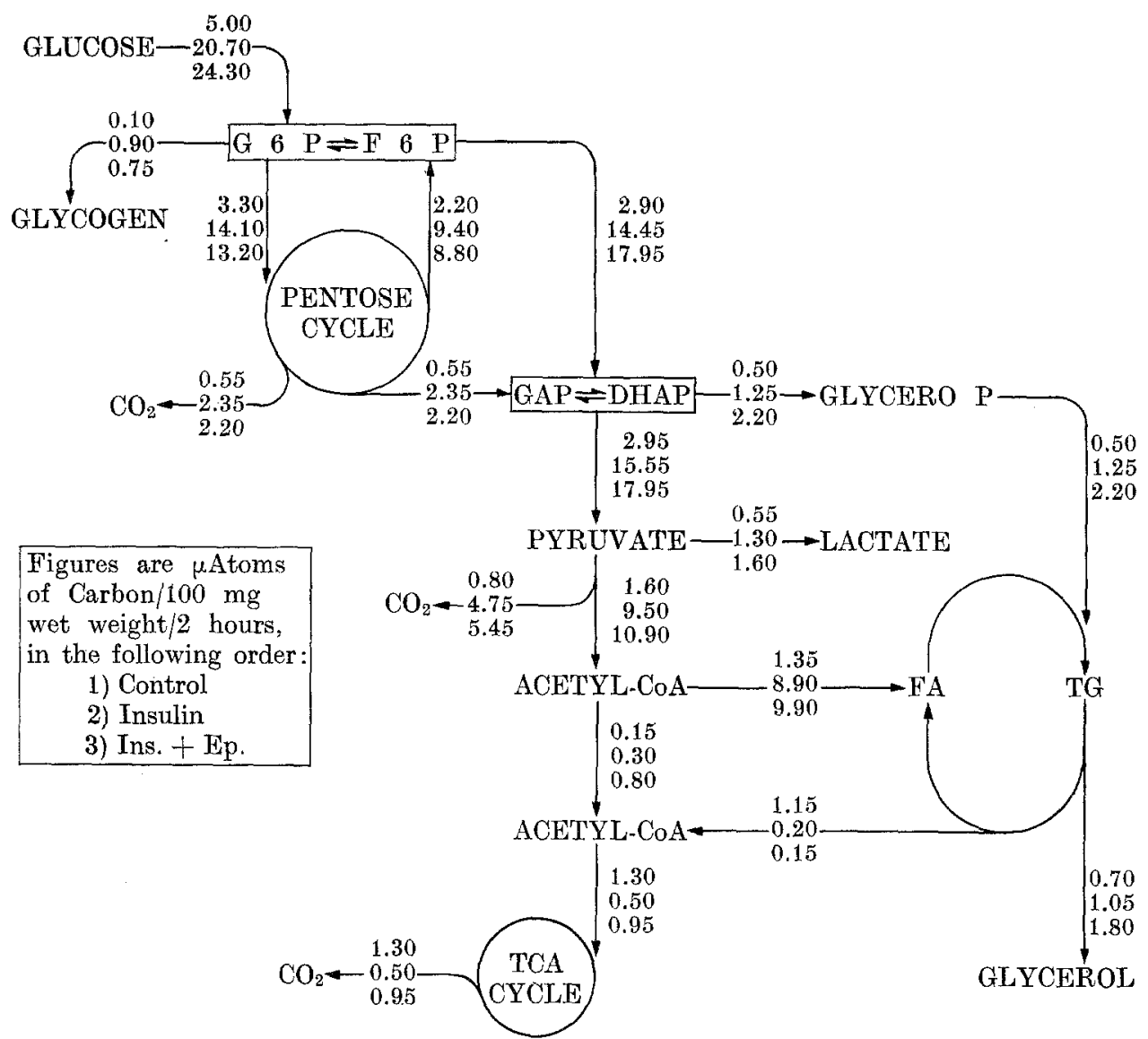

Fig. 4. The effect of insulin and insulin plus epinephrine on the flow of glucose carbon through various metabolic pathways in incubated rat epididymal adipose tissue. From J.P. FLATT and E.G. BAL, J. biol. Chem. 239, 675, 1964, and Chapter 26 in RENOHD and CAnسL, 1965

Glucose metabolism in any tissue can be considered as initially controlled by three events: diffusion from the vascular space or from the medium to the surface of the tissue cells; transport through the cell membrane, a process which in many tissues cannot be accounted for by simple diffusion; and metabolic activation of glucose, as a rule through phosphorylation to glucose-6. phosphate in the presence of ATP, appropriate ions and either hexokinase or glucokinase. In a well vascularized tissue, such as adipose tissue, with its dense network of capillaries and sinusoids, diffusion is probably controlled primarily through regulation of the plasma flow. Glucose phosphorylation has been studied by DiPietro (1963) in our laboratory in Boston and appears to be controlled by an enzyme similar to the hexokinase of yeast, brain or muscle, with an affinity for glucose sufficiently high (or a $\mathrm{K}_{\mathrm{m}}$ sufficiently small) to provide for its saturation at concentrations well below physiologically prevailing glucose concentrations in tissue fluids. DiPrerro concluded from his studies that it was unlikely that the phosphorylation step is the rate-controlling one in glucose utilization by adipose tissue, since increases in glucose concentration of the medium well above the physiologically prevailing concentrations result in accelerated glucose meta- bolism. Our principal interest, therefore, centred, from the start, on the step of glucose transport across the adipose cell membrane, the step also pointed to by Levarn's studies in vivo, as well as by the already mentioned studies with the isolated, perfused rat heart, or with rat hemidiaphragm.

From the extensive studies which have been carried out with striated muscle, erythrocytes, and yeast cells (reviewed by WILBRANDT, 1961 and 1963) it is known that in cells from which glucose is excluded by a diffusion barrier, there exist glucose transport systems at the level of the cell membrane, systems which fulfill the criteria of a transport system leading to facilitated diffusion and utilising a specific and mobile carrier. They exhibit stereospecificity and competition among pairs of sugars with structural similarities; saturation kinetics of the Michaelis-Menten type; and the steady state concentration of a transported but not metabolizable 
sugar is altered by the existence of a trans-membrane concentration gradient of a transported and metabolizable sugar, i. e. the phenomenon of "counter-transport" can be observed.

We have found that the transport system for glucose in adipose tissue conforms to these criteria in that it exhibits clearcut stereospecificity as best illustrated by its grossly decreased rate of L-glucose transport as compared with D-glucose (Figure 5). Unequivocal com-

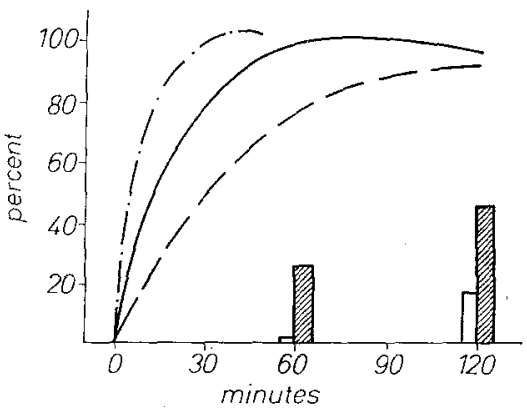

3-o-MethyI glucose - - - without insulin. D-Xylose* — with insulin - - - without insulin. I-Glucose: [IIII] with insulin $\square$ without insulin

Fig. 5. Time course of filling the intracellular space of incubated rat epididymal adipose tissue. The relative impermeability of the adipose tissue cell membrane to L-glucose. From CROFFORD and RENOLD, $1965 \mathrm{~b}$

* Data of MENOzzI P. G., BoGNANMI I. and BALESTRERI R. Arch. Maragliano Pat. Clin. 17,829 (1961)
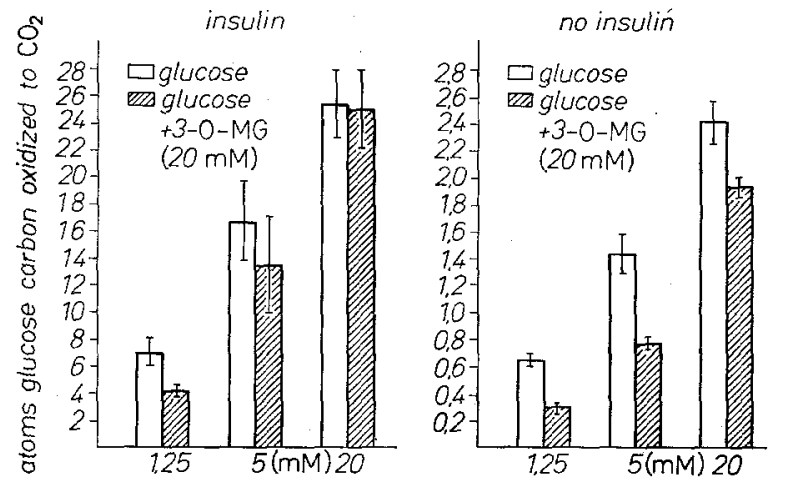

1 medium glucose concentration medium glucose concentration

Fig. 6. Inhibition of glucose oxidation by the non-phosphorylated sugar 3-o-methyl glucose as observed in incubated rat epididymal adipose tissue. From CRofrord and Renom, $1965 \mathrm{~b}$

petition for transport between sugars could be demonstrated by finding decreased glucose metabolism in the presence of increasing concentrations of 3-0-methyl glucose, a sugar that is transported but not phosphorylated (Figure 6). The transport of glucose and other sugars does exhibit, in the presence of increasing concentrations of sugar, the expected saturation kinetics. Also, phlorizin or its aglycone phloretin, substances which are well known to inhibit sugar transport in a large number of tissues or cells effectively inhibit glucose transport in adipose tissue (Fig. 7). Finally, and most important in our present view of the problem, the phenomenon of "counter-transport" is easily demonstrated in adipose tissue, as shown in the experi-

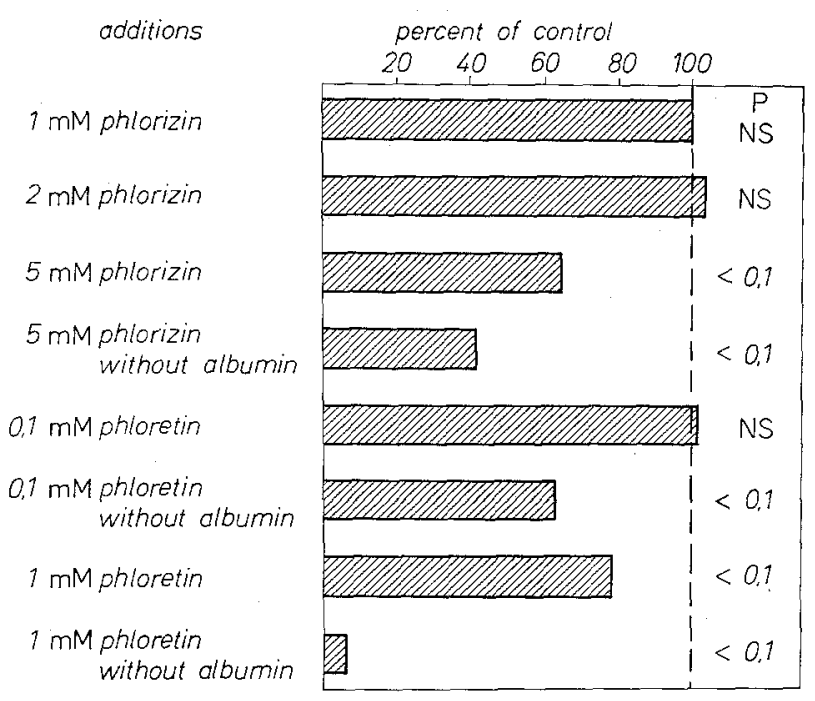

Fig. 7. Inhibition of glucose oxidation by the transport inhibitors phlorizin and phloretin in incubated rat epididymal adipose tissue. From CROFFORD and RENOLD, $1965 \mathrm{~b}$

ment illustrated by Figure 8: the addition of glucose to a flask where adipose tissue had come into equilibrium with medium containing 3-o-methylglucose resulted in the subsequent decrease of the intracellular 3-o-methylglucose concentration. This phenomenon is best explained as the result of the concentration gradient set up between glucose outside the cell and glucose inside the cell, since glucose within the cell is rapidly metabolized. Glucose therefore competes to a lesser degree for 3-omethylglucose outflow from the cell than for inflow, resulting in increase in the outward transport of 3-0methylglucose. Sucrose, a sugar which is neither transported nor metabolized, was used as an equiosmolar control substance and was without influence upon the intracellular 3-o-methylglucose concentration.

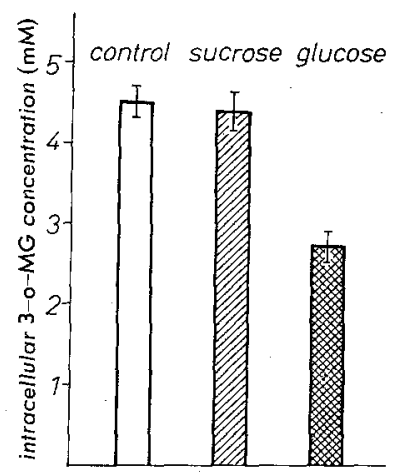

Fig. 8. Countertransport in incubated rat epididymal adipose tissue. Intracellular 3-0-methylglucose concentration after preincubation in $5 \mathrm{mM} 3-0$ methylglucose for $120^{\prime}$, followed by incubation in $5 \mathrm{mM}$ 3-0-methylglucose $+80 \mathrm{mM}$ sucrose or glucose for $30^{\prime}$. From CROFFORD and RErold, 1965 a

In this last experiment we have already assumed the rate limiting importance of transport for glucose metabolism in this tissue, since we have assumed the existence of a trans-membrane concentration gradient for glucose. The experimental basis for this assumption is 
shown in table 1 which summarizes a large number of experiments carried out under different conditions, where the sorbitol space was used as an expression of the extracellular space of adipose tissue. The talole also includes the demonstration that the major effect of insulin upon glucose metabolism by adipose tissue is that of accelerating glucose transport. In the first two lines it can be seen that the space occupied by glucose is smaller than the sorbitol space in the absence of insulin, suggesting that there is no free intracellular glucose and that diffusion of glucose is not quite capable of keeping up with glucose metabolism by the cells. The addition of insulin resulted in a striking increase in glucose uptake and, simultaneously, in a shrinking of the glucose space, clearly indicating that glucose diffusion into the tissue became still more inadequate in the presence of accelerated cellular utilization. Furthermore, this finding clearly establishes that insulin must

Table 1. Effect of insulin on glucose space (GS) and sorbitol space (SS) of incubated adipose tissue (fed rats)

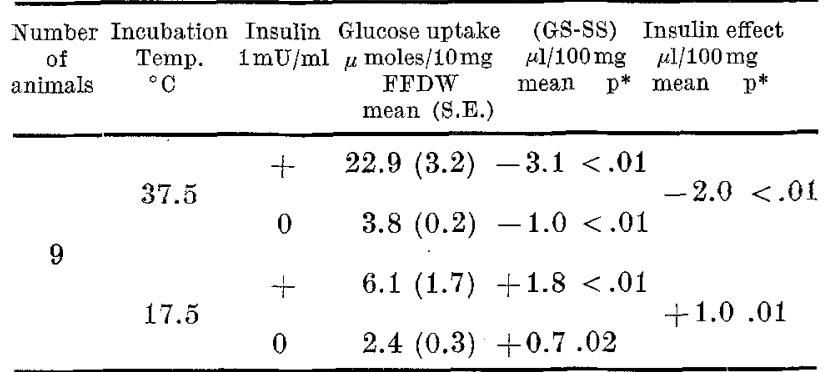

* Probability vs zero. medium glucose concentration, $20 \mathrm{~mm}$.

(from CROFFORD and RENOLD, 1965a)

act at the surface of the adipose tissue cell or beyond. The lower two lines of the table show the results obtained when the incubation temperature was decreased in order to decrease the metabolic rate and thus to achieve conditions where the regulating importance of glucose diffusion into the tissue would become less. Under these conditions, glucose space was slightly greater than the sorbitol space in the absence of insulin and became very definitely greater in its presence. This finding must mean that the presence of insulin resulted in the accumulation of free glucose within the cell, and thus that the insulin-induced acceleration of glucose metabolism was exerted not at the level of glucose phorphorylation, but just prior to intracellular free glucose, that is at the level of glucose transport through the cell membrane!

It is of considerable interest also that, working under conditions where we were unable to demonstrate free intracellular glucose at any concentrations used, the transport constant (Kt) for glucose was found to decrease by one order of magnitude in the presence of insulin, when compared with its value in the absence of insulin, an observation which can only be interpreted, as of the present, as indicating a greater affinity of some component of the transport system for glucose in the presence of insulin (CROFFord and RENoLd, 1965 b). Since we are well aware of the many pitfalls which presently surround conclusions drawn from the analy. sis of transport kinetics, conclusions which must still accept several assumptions which are difficult to prove, we do not want to emphasize this finding too strongly, even though it does differ from what has been found for the action of insulin in muscle (MoRgar et al. 1964). The observation, however, is entirely in keeping with what might theoretically be expected (LEFEVRE, 1962).

When a hormonal effect is described in vitro, it is of course comforting to know that the same effect can also be seen in vivo. That large concentrations of insulin directly act upon adipose tissue in vivo to increase its glucose metabolism was already apparent from our very first studies (Figure 2) as well as from the studies

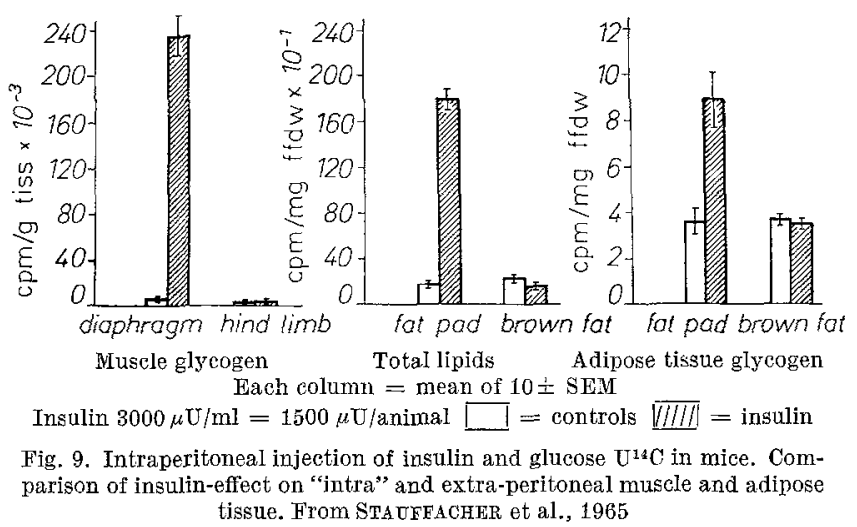

of FAVARGER carried out in vivo in mice (FAVARGER and BODUR, 1956). We have recently continued with work initiated by RAFAELSFN, in collaboration with our group in Boston, in which the localized, yet in vivo response of tissues lining the peritoneal cavity to small amounts of insulin, injected intraperitoneally, was analyzed (RAFAELSEN et al. 1965). This localized response is shown for both diaphragm and peritoneal adipose tissue in the experiments illustrated in Figure 9 which demonstrates the remarkable effectiveness of small doses of insulin apon these tissues, when compared with its total lack of effectiveness on distant tissues of the same type. Clearly, in vivo as well as in vitro, a direct insulin effect on adipose tissue was seen. In more recent studies this method has been used by us for the comparative analysis of adipose tissue and muscle metabolism and of the relative sensitivity of these tissues to insulin in normal and in several types of genetically obese mice (STAUFFACHER et al. 1965).

A most remarkable development of recent years has been the report by RoDBELL $(1964,1965)$ that it is possible to obtain free adipose tissue cells through incubation of the tissue with collagenase preparations, with their subsequent separation from other cells, such as connective tissue cells, through repeated floating in buffer. RODBELL also reported that these cells remained sensitive to hormonal agents such as insulin or adrena- 
lin. We have fully confirmed RoDBELL's work and Figure 10 illustrates the effect of insulin upon free fat cells as well as the intriguing observation, made in certain instances, that the cells so obtained may rapidly loose their insulin sensitivity, without any obvious change in their appearance under the microscope or in their basic metabolic behaviour. It is possible that the analysis of this phenomenon might contribute to a better understanding of the requirements for insulin responsiveness of the adipose cell membrane.

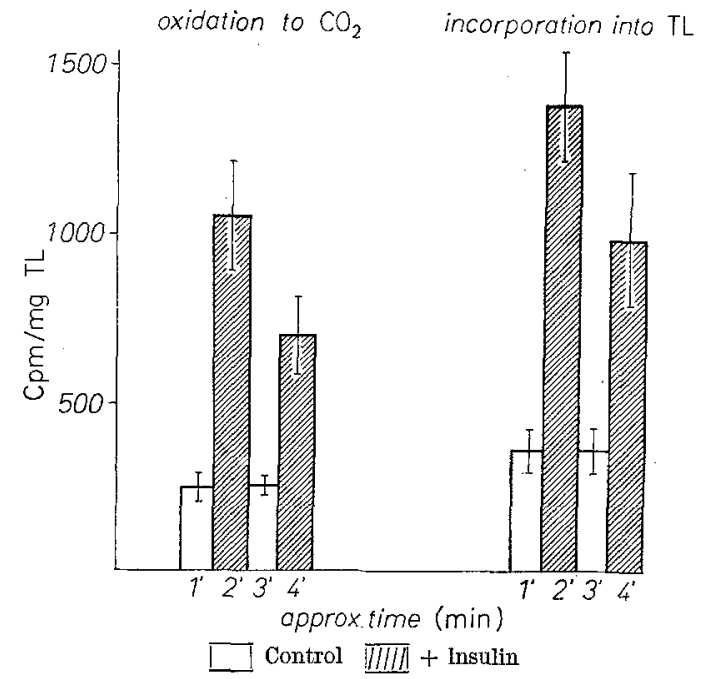

Fig. 10. Glucose-U $\mathrm{U}^{14} \mathrm{C}$ Metabolism by free fat cells of rat epididymal adipose tissue, in vitro. Decrease in the insulin effect with time. Incubation 2 hours at $37^{\circ} \mathrm{C}$ in $0.5 \mathrm{ml}$ of albumin-bicarbonate buffer $p H 7.4$ containing $2.5 \mathrm{mMI}$ glucose. Insulin, when added, $1 \mathrm{mV} / \mathrm{ml}$. Fed rats. Results expressed as $\mathrm{cpm}$ per mg of total lipids contained in the adipose cell suspensions. Each column: mean of 6 values, $\pm S$. F. JFANRBNAUD, unpublished observations

Although we have emphasized the effect of insulin upon glucose entry into adipose tissue cells, it would seem quite certain today that insulin also exerts effects on adipose tissue, which are not readily related to glucose utilization. Among these, emphasis should be given to the very likely existence of a direct effect of insulin on free fatty acid release by adipose tissue, an effect which was suggested from the start by the very profound and rapid decline in free fatty acids which follows the administration of insulin in vivo (Figure 1). However, it was first thought that this decreased rate of release of free fatty acids could be related to the increased availability of $\alpha$-glycerol-phosphate for reesterification of free fatty acids within the tissue, as a result of increased availability of intracellular glucose (Figure 3). Since free fatty acids and adipose tissue glycerides are in a state of dynamic equilibrium, acceleration of re-esterification, without change in the rate of lipolysis, would result in a net decrease in the release of free fatty acids. However, it has now been shown unequivocally, and by several groups of investigators (Jungas and Ball, 1963, Mahler et al. 1964, Fromsch et al. in RENOLD et al., 1965), that an effect of insulin upon lipolysis may be seen in the total absence of glucose. Just how insulin does this, is as yet unknown, although it is not impossible that the effect might also be on membrane transport. The effect would be one of decreasing the transport of free fatty acids through the cell membrane (Figure 3, No. 4). Indeed, such a suggestion has recently been made by ZIERLER et al. (1965), while MAHLER et al. (1964) favour the interpretation of an effect upon the lipolytic reaction itself (Figure 3, No. 2).

The subject of the effect of insulin on adipose tissue should not be reviewed, even in this summary fashion, without emphasizing that the interaction may be a much more complex one than might be apparent from what has been said so far. Insulin alters the transmembrane electric potential both in the presence and in the absence of glucose (BEIGELMAN and HoLLANDER, 1962 and 1964); insulin has been reported to accelerate pinocytosis in adipose tissue cells (BARNETT and BALL, 1960); adipose tissue obtained from insulin-deprived alloxan diabetic animals exhibits a decrease in its ability to store chylomicron-fat concurrently with a decrease in adipose tissue lipoprotein lipase activity (Schratz and Williams, 1962), an activity essential for the hydrolysis of chylomicron triglyceride which must precede its incorporation into adipose tissue stores; also, the oxidation of long chain fatty acids to mono-enoic acids is clearly impaired in the tissue from diabetic animals (Benjamin and GeLLHORN, 1964). The complex picture of some of the anomalies seen in adipose tissue from diabetic animals is summarized in Figure 11.

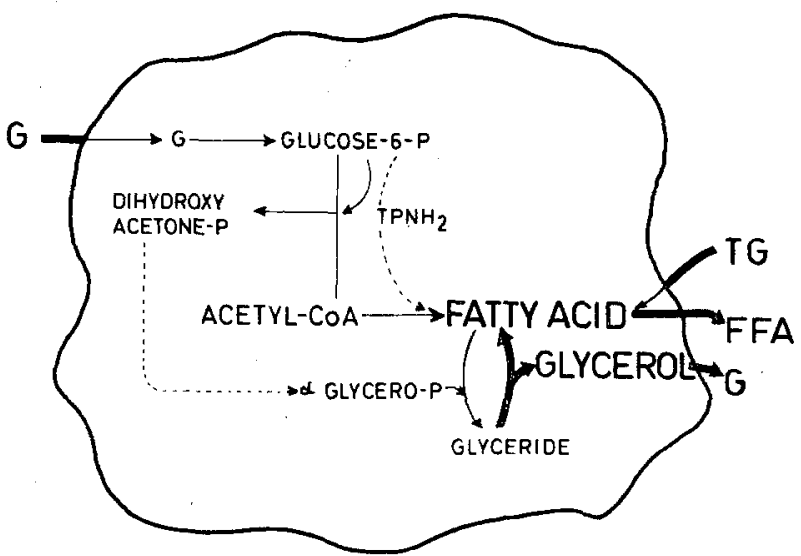

Fig. 11. Schematic representation of major metabolic defects in diabelio adipose tissue

Finally, it may be important to consider not only what insulin does to adipose tissue, but also what adipose tissue does to insulin, or rather to the insulin-like activity of serum. As first reported by ANToniades and GUNDERSEN (1961) and fully confirmed by SHAw and SHuex (1963) certain extracts of adipose tissue are eapable of increasing that portion of insulin activity of normal human serum which is measured by the stimulation of glycogen synthesis in rat diaphragm and which can be suppressed by the addition of anti-insulin serum. 
How shall we summarize? Despite the complicating features which have been mentioned, it would none the less seem reasonable to conclude that the effect of insulin upon adipose tissue cells is primarily one of increasing the glyceride stores through increased availability of glucose to the metabolism of the adipose cell. This effect may well be enhanced by an additional action of insulin resulting in a decreased rate of Jipolysis and of free fatty acid release from the tissue. Furthermore, it would seem that insulin is the major physiologic regulator increasing adipose tissue glyceride stores. Although insulin-like effects of other substances, even of a number of hormones, have been described, very few of them occur at concentrations likely ever to occur in plasma and they rarely correspond to in vivo physiologic events. We are left, therefore, with a reasonably simple view of the regulation of the deposition and retention of fat in adipose tissue, particularly when compared with the extremely complex present view of lipid mobitization from adipose tissue. Figure 12 is taken from a re-

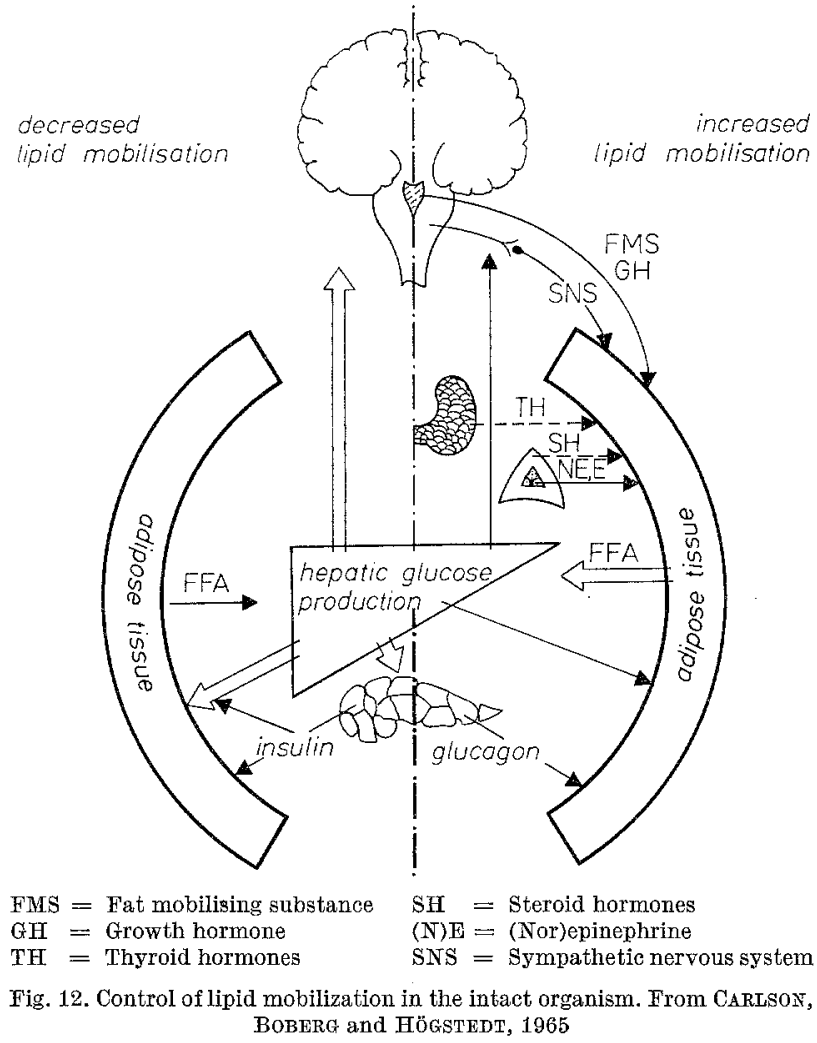

cent review of CARLSON and collaborators (1965) summarizing some of the factors concerned with the mobilization of lipids: contrast the rather simple left hand side of the illustration concerned with decreased lipid mobilization, where the only agent shown, insulin, is furthermore also the agent primarily responsible for increased lipid deposition, with the complexity of the right hand side of the figure, concerned with the many systems and agents presently known to increase lipid mobilization!
An additional complicating feature on the lipid mobilization side, which we would like to mention and with which we shall end this discussion, concerns the hitherto largely ignored factor of blood or plasma flow through adipose tissue. Table 2 , which shows data of RoDbelu (1965), compares the free fatty acid release by intact adipose tissue with that by free adipose cells from the same tissue. In the presence of a lipolytic

Table 2. FFA Release by intact adipose tissue and free fat cells in response to $A C T H$ (Data of Rodbell)

\begin{tabular}{|c|c|c|c|}
\hline & $\begin{array}{c}\text { ACTH } \\
(2 \mu \mathrm{g} / \mathrm{ml})\end{array}$ & $\begin{array}{l}\text { total FFA } \\
\text { in flasks }\end{array}$ & $\begin{array}{c}\text { net } \\
\text { FFA release } \\
\text { due to ACTH }\end{array}$ \\
\hline Tissue & - & $6.4 *$ & \\
\hline \multirow{3}{*}{ Cells } & + & 15.4 & $+9 * *$ \\
\hline & - & 4.6 & \\
\hline & + & 107.6 & +103 \\
\hline
\end{tabular}

agent, in this case ACTH, it is evident that lipolysis was almost ten times as great for the cells as for the intact tissue. This is almost certainly the result of the very much greater availability of albumin to the surface of the free cells, since albumin, the carrier which accepts and transports free fatty acids in the bloodstream, is essential to successful lipolysis. If greater or lesser availability of albumin may increase the effectiveness of a lipolytic agent tenfold, then surely the rate at which albumin is presented to the adipose tissue cells is likely to be one of the major controlling factors of free fatty acid release by adipose tissue and, secondarily, of glyceride breakdown! Accordingly, blood and plasma flow, particularly the latter (since a major part of adipose tissue sinusoids seems to be perfused by plasma only) undoubtedly modulate the activity of fatty acid mobilization in any given portion of adipose tissue. Indeed, the observation that sympathetic nervous endings in adipose tissue are seen only in connection with small blood vessels (WIRSEN, 1964) not with the adipose cells themselves, raises the question as to the likelihood of a major component of autonomic nervous system effects upon adipose tissue being secondary to effects upon plasma flow!

References. Antontades, H.N., and K. Gundersen: Studies on the state of insulin in blood: dissociation of purified human blood insulin complexes by incubation with adipose tissue extracts in vitro. Endocrinology 68, 36-42 (1961). - Barnett, R., and E. G. BALL: Metabolic and ultra-structural changes induced in adipose tissue by insulin. J. Biophys. Biochem. Cytol. 8, 83-101 (1960). - Beigelmar, P.M., and P.B. Hollander: Effect of insulin upon resting electrical potential of adipose tissue. Proc. Soc. Exp. Biol. Med. 110, 590-595 (1962); - Effects of hormones upon adipose tissue mem. brane electrical potentials. Proc. Soc. Exp. Biol. Med. 116, $31-35$ (1964). - Benjamin, W., and A. Gellihorn: The effect of diabetes and insulin on the biosynthesis of individual fatty acids in adipose tissue. J. Biol. Chem. 239, 64-69 (1964). - CaHiLl, G.F., B. Jeanrenaud, B. 
Leboeuf and A. E. Renold : Effects of insulin on adipose tissue. Ann. N.Y. Acad. Sci. 82, 403-411 (1959a). CAHILl, G. F., Jr., B. Leboeuf and A. E. Renold : Studies on rat adipose tissue in vitro. III. Synthesis of glycogen and glyceride glycerol. J. Biol. Chem. 234, 2540-2543 $(1959 \mathrm{~b})$. - CARLson, L.A., J. BoberG, and B. HögSTEDT: Some physiological and clinical implications of lipid mobilization from adipose tissue, chapter 63, in Renold and Cahill, 1965. - CRofford, O.B., and A.E. RENOLD : Insulin and glucose transport in adipose tissue. In: Abstracts of communications presented at the First Meeting of the Federation of European Biochemical Societies, p. 99 London 1964; - Glucose uptake by incubated rat epididymal adipose tissue. Rate-limiting steps and site of insulin action. J. Biol. Chem. 240, 14-21 (1965a); - Glucose uptake by incubated rat epididymal adipose tissue: characteristics of the glucose transport system. J. Biol. Chem. in press, $(1965 \mathrm{~b})$. - DipieTro, D.L.: Hexokinase of white adipose tissue. Biochim. Biophys. Acta 67: 305-312 (1963). - DoLE, V.P.: A relation between non-esterified fatty acids in plasma and the metabolism of glucose. J. Clin. Invest. 35, 150-154 (1956). - Favarger, P., and H. Bodur: The effect of insulin on the synthesis of fats in mouse adipose tissue, in vivo. J. Physiol. (Paris) 48, 534-537 (1956). - GoRdon, R.S., Jr., and A. Cherkes: Unesterified fatty acid in human blood plasma. J. Clin. Invest. 35, 206-212 (1956); - Production of unesterified fatty acids from isolated rat adipose tissue incubated in vitro. Proc. Soc. Exp. Biol. Med. 97, 150-151 (1958). - HAUSBERGER, F.X., S.W. Mrlstein, and R.J. Ruturan: The influence of insulin on glucose utilization in adipose and hepatic tissues in vitro. J. Biol. Chem. 208, 431-438 (1954). - JunGas, R.L., and E.G. BALL: Studies on the metabolism of adipose tissue. XII. The effects of insulin and epinephrine on free fatty acid and glycerol production in the presence and absence of glucose. Biochemistry 2, 383-388 (1963). Kenwick, A.: On adiposity. Brit. Med. J. 1946 II, 407 -414. - KiPNIS, D. M. : Regulation of glucose uptake by muscle. Functional significance of permeability and phosphorylating activity. Ann. N.Y. Acad. Sci. 82, 354-365 (1959). - KRAHL, M.E.: The effect of insulin and pituitary hormones on glucose uptake in muscle. Ann. N.Y. Acad. Sci. 54 649-670 (1951). - LAurell, S.: Plasma free fatty acids in diabetic acidosis and starvation. Scand. J. Clin. Lab. Invest. 8, 81-82 (1956). - LAWRENCE, R.D.: Lipodystrophy and hepatomegaly with diabetes, lipemia and other metabolic distrubances. A case throwing new light on the action of insulin. Lancet 1946 I, 724, 773 - LeFEvRe, P. G.: Rate and affinity in human red blood cell sugar transport. Am. J. Physiol. 203, 286-290 (1962), - Levine, R., and M. Goldstein: On the mechanism of action of insulin. Recent Progr. Hormone Res. 11, 343375 (1955). - MAHLER, R., W.S. STAFFORD, M.E. TARRANT and J. ASHMORE: The effect of insulin on lipolysis. Diabetes 13, 297-302 (1964). - MorgaN, H.E., D.M. REGEN and C.R. PARK: Identification of a mobile carriermediated sugar transport system in muscle. J. Biol. Chem. 239, 369-374 (1964). - PARK, C.R., D. ReInwern, M.J. Henderson, E. Cadenas and H. Morgan: The action of insulin on the transport of glucose through the cell membrane. Am. J. Med. 26, 674-684 (1959). - Rafaetsen,
O.L., V. LaURIs and A.E. Renold: Localized intraperitoneal action of insulin on rat. Diaphragm and epididymal adipose tissue in vivo. Diabetes 14, 19-26 (1965). RaNDLE, P.J., and H.E. MorgaN : Regulation of glucose uptake by muscle. Vitamins Hormones 20, 199-249 (1962). - Renold, A.E., and G.F. CAHILL, Jr., Editors: Handbook of Physiology, Section 5: Adipose Tissue. Am. Physiol. Soc. Washington, D.C., distributed by Williams and Wilkins, Baltimore, Maryland (1965). - RENOLD, A.E., A. Marble and D.W. FawcetT: Action of insulin on deposition of glycogen and storage of fat in adipose tissue. Endocrinology 46, 55-66 (1950). Renold, A.E., A.I. Winggard and D.B. Martin: Diabetes mellitus and adipose tissue. Helv. Med. Acta 24, 322-327 (1957). - RENOLD, A.E., B. JEANRENAUD, A.I. Winegrad and D.B. Martin: Adiopse tissue: a major site of metabolic interrelation between carbohydrates and fats. In: Modern Problems in Pediatrics, vol. 4 p. 120, edited by S. Karger. Basel, Switz. 1959. - RENOLD, A.E., A.I. Winegrad, B. Jeanrenaud and D.B. Martin: Suggested importance of adipose tissue as a site of insulin action and as a major site of metabolic interrelations between carbohydrates and fats. In: The Mechanism of Action of Insulin p. 153, Oxford: Blackwell Scientific Publications, Ltd. 1960. - Renold, A.E., O.B. CrofFORD, H. BÜRGI and E.R. Froesch: Insulin and the metabolism of adipose tissue. In: G.A. Wrenshall and B.S. Leibel, Editors. On the Nature and Treatment of Diabetes, Excerpta Medica Foundation, Amsterdam, The Netherlands, in press, 1965. - RodBELI, M. : Metabolism of isolated fat cells. I. Effects of hormones on glucose metabolism and lipolysis. J. Biol. Chem. 239, 375-380 (1964); - The metabolism of isolated fat cells. Chapter 47. In: RENOLD and CAHILL, 1965. - SchNatz, J.D., and R. H. WiLliams: The effect of acute insulin, deficiency in the rat on adipose tissue lipolytic activity and plasma lipids. Diabetes 12, 174-178 (1963). - SHAW, W.N., and E.W. SHUEY: The presence of two forms of insulin in normal human serum. Biochemistry $2,286-289(1963)$. - STAUFFACHER, W., O.B. Crofford, B. JEANRENAUD and A.E. RENOLD : Comparative studies of muscle and adipose tissue metabolism in non-obese and obese mice. Ann. N.Y. Acad. Sci., in press, 1965. - Werthemer, E., and B. ShaprRo: The physiology of adipose tissue. Physiol. Rev. 28, 451-464 (1948). - WILBRANDT, W., and T. ROSENBERG: The concept of carrier transport and its corollaries in pharmacology. Pharmacol. Rev. 13, 109-183 (1963). WILBRANDT, W.: Transport through biological membra. nes. Ann. Rev. Physiol. 25, $601-630$ (1963). - WineGRAD, A.I., and A.E. RENOLD: Studies on rat adipose tissue in vitro. I. Effects of insulin on the metabolism of glucose, pyruvate and acetate. J. Biol. Chem. 233, 267$272(1958 \mathrm{a})$; - Studies on rat adipose tissue in vitro. II. Effects of insulin on the metabolism of specifically labelled glucose. J. Biol. Chem. 233, 273-276 (1958b). - WIRSEN, C.: Adrenergic innervation of adipose tissue examined by fluorescence microscopy. Nature 202, 913 (1964).

Prof. Dr. A. E. Reroud Institut de Biochimie Clinique Sentier de la Roseraie Genève/Suisse 